\title{
Tanggung Jawab Perusahaan Perencana Keuangan Penyedia Program Investasi yang Merugikan Konsumen Dihubungkan dengan Teori Kepastian Hukum
}

\author{
Vivi Nur Arzy ${ }^{1}$, Yeti Sumiyati ${ }^{2}$
}

1 ProgramStudi Magister Ilmu Hukum Universitas Islam Bandung, E-mail: vivinura104@gmail.com 2 ProgamStudi Magister Ilmu Hukum Universitas Islam Bandung, E-mail: yeti@unisba.ac.id

\begin{tabular}{l}
\hline Info Artikel \\
\hline Masuk:30 April 2021 \\
Diterima:25 September 2021 \\
Terbit:30 September 2021 \\
Keywords: \\
Financial Planner; Corporate \\
Liability; Legal Certainty \\
\\
\\
\\
Corresponding Author: \\
Vivi Nur Arzy, E-mail: \\
vivinura104@gmail@gmail.com \\
DOI: \\
10.24843/IMHU.2021.v10.i03.p08 \\
Kata kunci: \\
Jawab Perusahaan; Kepastian \\
Hukum \\
\end{tabular}

\begin{abstract}
The principle of responsibility as one of the principles of GCG is reflected in the Company Law that every company in carrying out activities must not conflict with the law. The principle of responsibility can also be applied to companies engaged in the capital market. A financial planning company is a company whose activities intersect with the capital market and can support the capital market. However, the financial planning company in this case PT. Jouska Financial Indonesia carries out activities under the authority of investment managers that cause harm to consumers. The purpose of this study is to examine the laws and regulations governing investment programs carried out by financial planning companies and the responsibilities of financial planning companies providing investment programs that harm consumers associated with legal certainty. This research is a normative legal research using a conceptual approach and a statutory approach. The analytical method uses legal construction through the analogy method used to find specific provisions into general provisions so that they can be applied to financial planners. From this research, it can be conduded that: First, the regulation regarding financial planners in the laws and regulations in Indonesia has not been specifically and specifically regulated so that the existence of financial planners has not received legal certainty. Second, responsibility for financial planning companies providing investment programs that harm consumers can be subject to administrative, civil and criminal sanctions.
\end{abstract}

\begin{tabular}{l}
\hline Abstrak \\
\hline Prinsip responsibility sebagai salah satu prinsip GCG tercermin \\
dalam UUPT bahwa setiap perusahaan dalam melaksanakan \\
kegiatan tidak boleh bertentangan dengan undang-undang. \\
Prinsip responsibility ini juga dapat diterapkan pada perusahaan \\
yang bergerak dalam bidang pasar modal. Perusahaan perencana \\
keuangan merupakan perusahaan yang dalam kegiatannya \\
berivisan denganpasar modal dan dapat menunjang pasar modal. \\
Namun, perusahaan perencana keuangan dalam hal ini PT. \\
Jouska Financial Indonesia melakukan aktivitas yang menjadi \\
kewenangan manajer investasi yang menyebabkan kerugian bagi \\
konsumen. Tujuan dari penelitian ini adalah untuk mengkaji \\
peraturan perundang-undangan yang mengatur tentang \\
program investasi yang dilakukan oleh perusahaan perencana
\end{tabular}




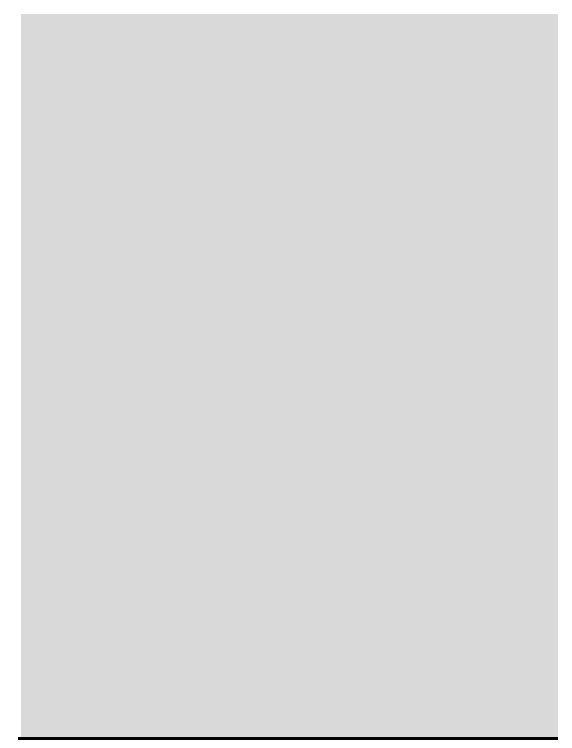

\begin{abstract}
keuangan dan tanggung jawab perusahaan perencana keuangan penyedia program investasi yang merugikan konsumen dihubungkan dengan kepastian hukum. Penelitian ini merupakan penelitian hukum normatif dengan menggunakan pendekatan konseptual dan pendekatan perundang-undangan. Metode analisis menggunakan konstruksi hukum melalui metode analogi yang digunakan untuk mencari ketentuan yang khusus menjadi ketentuan umum agar bisa diterapkan terhadap perencana keuangan. Dari penelitian ini dapat disimpulkan bahwa: Pertama, pengaturan mengenai perencana keuangan dalam peraturan perundang-undangan di Indonesia belum diatur secara spesifik dan khusus sehingga keberadaan perencana keuangan belum mendapatkan kepastian hukum. Kedua, tanggung jawab terhadap perusahaan perencana keuangan penyedia program investasi yang merugikan konsumen dapat dikenakan sanksi administratif, perdata, dan pidana.
\end{abstract}

\title{
I. Pendahuluan
}

Pengaturan mengenai Good Corporate Governance (GCG) di Indonesia terdapat dalam Peraturan Menteri BUMN Nomor PER-09/MBU/2012 tentang Perubahan Atas Peraturaan Menteri BUMN Nomor PER-01/MBU/2011 tentang Penerapan Tata Kelola Perusahaan yang Baik (Good Corporate Governance) Pada Badan Usaha Milik Negara. Prinsip pertanggungjawaban atau yang biasa disebut dengan prinsip responsibility adalah salah satu bagian dari prinsip GCG. Prinsip responsibility ini memiliki arti bahwa dalam pengelolaan perusahaan harus terdapat kesesuaian dengan peraturan perundang-undangan yang berlaku dan prinsip perusahaan yang sehat. Baik perusahaan swasta ataupun BUMN pengelolaannya harus taat dan dilandaskan pada perundang-undangan sebagai wujud kepatuhan dalam menjalankan prinsip responsibility. ${ }^{1}$ Prinsip responsibility dapat terimplementasi dengan baik apabila organ perusahaan senantiasa berpegang teguh dan mematuhi segala peraturan yang ada dalam perusahaan mulai dari peraturan perundang-undangan, peraturan perusahaan, anggaran dasar serta harus dijalankan dengan penuh kehati-hatian. ${ }^{2}$

Prinsip responsibility tercermin dalam Undang-Undang Nomor 40 Tahun 2007 tentang Perseroan Terbatas terutama dalam Pasal 2 dan 18 UUPT yang mengatur bahwa dalam anggaran dasar perusahaan harus dicantumkan maksud, tujuan, dan kegiatan usaha perusahaan yang tidak boleh bertentangan dengan ketentuan perundang-undangan, ketertiban umum, dan/atau kesusilaan. Perusahaan yang tidak melaksanakan ketaatan terhadap peraturan perundang-undangan dalam hal ini melanggar prinsip

\footnotetext{
${ }^{1}$ Suseno Adi Wibowo and Yeti Sumiyati, “Tanggung Jawab Korporasi Fintech Lending Ilegal Dalam Perspektif Perlindungan Konsumen [Corporate Liability of Illegal Fintech Lending in the Perspective of Consumer Protection Law]," Law Review, 2021,117-44.

2 Efridani Lubis and Haryogis Susanto, "Penerapan Good Corporate Governance Di Pasar Modal Sebagai Upaya Melindungi Investor," Jurnal Hukum Dan Bisnis (Selisik) 5, no. 1 (2019): 48-76.
} 
responsibility, maka bertanggung jawab secara pribadi atas kerugian yang ditimbulkan, kecuali apabila dapat dibuktikan sebaliknya. ${ }^{3}$

Prinsip responsibility berlaku juga untuk perusahaan yang bergerak dalam bidang pasar modal karena setiap perusahaan yang bergerak dalam sektor pasar modal harus berbentuk PT, ketentuan perihal pasar modal diatur dalam Undang-Undang Nomor 8 Tahun 1995 tentang Pasar Modal. Perusahaan yang bergerak di pasar modal merupakan perusahaan publik atau perusahaan terbuka, artinya masyarakat harus mengetahui segala aktivitas perusahaan dan saham perusahaan dapat dimiliki oleh masyarakat. Perusahaan yang kegiatan usahanya bergerak di pasar modal dalam melakukan aktivitasnya mengandung resiko tinggi, maka melalui prinsip-prinsip GCG perusahaan dapat meminimalisir dampak yang tidak diinginkan agar kepercayaan masyarakat terhadap pasar modal tetap terjaga ${ }^{4}$, dan dapat melindungi investor, pemegang saham publik serta masyarakat.

Setiap perusahaan yang bergerak dalam bidang pasar modal wajib didaftarkan dan memiliki izin dari Otoritas Jasa Keuangan. OJK berfungsi untuk mengatur, membina, dan mengawasi setiap aktivitas yang ada di pasar modal, hal ini bertujuan agar menciptakan aktivitas pasar modal yang tertib, proposional dan efisien, selain itu juga dapat melindungi masyarakat dan pemodal. Dalam Pasal 5 Undang-Undang Nomor 21 Tahun 2011 tentang Otoritas Jasa Keuangan, menyebutkan bahwa OJK memiliki fungsi sebagai penyelenggara sisten pengaturan dan pengawasan yang terintegrasi pada seluruh aktivitas dalam sektor jasa keuangan. Artinya, suatu perusahaan harus terdaftar di OJK jika akan menyediakan jasa layanan investasi sepuaya terusahaan tersebut bisa beroperasi secara legal. Oleh karena itu, seluruh perusahaan yang bergerak dan menunjang kegiatan pasar modal seharusnya tunduk dalam UUPM dan peraturan OJK.

Perencana keuangan merupakan suatu profesi yang beririsan dengan pasar modal dan dapat menunjang pasar modal, yang bertujuan agar membantu memberikan rencana finansial bagi nasabahnya sehingga dapat tercapai tujuan keuangan jangka pendek, menengah, dan panjang. Perencana keuangan ini dapat dijalankan secara sendiri maupun dalam bentuk perusahaan. Di Indonesia dikenal jenis perencana keuangan yaitu perencana keuangan independen yaitu perencana keuangan yang tidak terikat pada perusahaan tertentu, dan perencana keuangan terikat yaitu perencana keuangan yang bekerja atau terikat pada lembaga tertentu. ${ }^{5}$ Perencana keuangan seharusnya tunduk pada POJK, karena semua yang bergerak dalam sektor jasa keuangan khususnya dalam pasar modal maka pengawasan dan pengaturannya berada di bawah kewenangan OJK. Namun peraturan mengenai perencana keuangan belum diatur secara khusus, OJK telah merencanakan akan mengatur mengenai perencana

\footnotetext{
${ }^{3}$ Mohamad Iqbal Fauzi and Yeti Sumiyati, "Pertanggungjawaban Developer Perumahan Terhadap Pembangunan Di Kawasan Resapan Air Prespektif Hukum Nasional Dan Hukum Islam," Asy-Syari'ah 23, no. 1 (2021): 103-24.

4 Lubis and Susanto, "Penerapan Good Corporate Governance Di Pasar Modal Sebagai Upaya Melindungi Investor."

${ }^{5}$ Allianz Indonesia, "Yuk, Mengenal Profesi Perencana Keuangan Yang Tengah Hits!," accessed April 9, 2021, https://www.allianz.co.id/explore/yuk-mengenal-profesi-perencanakeuangan-yang-tengah-hits $h t m l$.
} 
keuangan dari tahun 20146, tetapi sampai saat ini peraturan tersebut masih belum terealisasikan.

Selama ini peraturan mengenai perencana keuangan hanya sebatas kode etik dan standar profesi yang dikeluarkan oleh Financial Planing Standards Board (FPSB) sebagai lembaga sertifikasi perencana keuangan. Peraturan mengenai perencana keuangan belum dikeluarkan oleh OJK. Pemerintah baru mengeluarkan peraturan yang berkaitan dengan perencana keuangan yaitu Peraturan Pemerintah Nomor 43 Tahun 2015 tentang Pihak Pelapor dalam Pencegahan dan Pemberantasan Tindakan Pidana Pencucian Uang serta Peraturan PPATK Nomor 6 Tahun 2017 tentang Penerapan Prinsip Mengenali Pengguna Jasa bagi Perencana Keuangan yang bertujuan untuk melindungi perencana keuangan dari penyelewengan konsumennya yang melakukan tindak pidana pencucian uang. Akan tetapi kedua peraturan tersebut belum memberikan apa yang menjadi kewenangan, tanggung jawab, perlindungan hukum, serta sanksi bagi perencana keuangan. Peraturan yang telah ada masih belum memadai sehingga mengakibatkan keberadaan perencana keuangan belum mendapatkan kepastian hukum.

Pada tahun 2020, terdapat perusahaan perencana keuangan yang tidak hanya melaksanakan aktivitas memberikan edukasi mengenai keuangan/investasi, merencanakan suatu strategi dan tujuan keuangan/investasi, membantu mencapai tujuan keuangan/investasi yang sedang dibutuhkan oleh konsumen, konsultasi investasi, dan memberikan solusi atas permasalahan keuangan konsumen tetapi juga dia mengeluarkan program investasi, bertransaksi jual beli (trading) protofolio, turut mengelola dan menempatkan dana konsumennya di instrumen investasi tertentu. PT. Jouska Financial Indonesia (Jouska) yang merupakan perusahaan perencana keuangan melakukan telah tindakan penyimpangan terhadap maksud dan tujuan perseroan yang semula sebagai perusahaan perencana keuangan menjadi bertindak sebagai manajer investasi. Atas perbuatan penyimpangan yang telah dilakukan oleh Jouska, konsumen yang menggunakan jasa Jouska mendapatkan kerugian akibat Jouska telah menempatkan dana konsumen secara serampangan.

Kajian dalam artikel ini berbeda apabila dibandingkan dengan artikel yang telah dikaji sebelumnya dengan topik yang sama. Hal ini dapat dilihat melalui artikel Abdul Rokhim (2020) yang pada intinya menyimpulkan akibat hukum dari tindakan direksi yang melakukan tindakan intra vires dan ultra vires.7 Selain itu, artikel dari Desak Made Setyarini, Ni Luh Made Mahendrawati, dan Desak Gde Dwi Arini (2020) yang menekankan pada bentuk-bentuk perbuatan melawan hukum yang dilakukan direksi dalam mengurus perseroan serta tanggung jawabnya. ${ }^{8}$ Kemudian artikel dari Efridani Lubis dan Haryogis Susanto (2019) yang menekankan penerapan GCG di pasar

\footnotetext{
${ }^{6}$ Sakina Rakhma Diah Setiawan, “OJK Rumuskan Aturan Pengawasan Perencana Keuangan," accessed April 5, 2021, https:/ / money.kompas.com/read/2014/02/28/1521518/OJK.Rumuskan.Aturan.Pengawasa n.Perencana.Keuangan.

${ }^{7}$ Abdul Rokhim, “Tindakan 'ULTRA VIRES' Direksi Dan Akibat Hukumnya Bagi Perseroan Terbatas," Negara Dan Keadilan 9, no. 2 (2020): 205-17.

8 Desak Made Setyarini, Ni Luh Mahendrawati, and Desak Gde Dwi Arini, "Pertanggungjawaban Direksi Perseroan Terbatas Yang Melakukan Perbuatan Melawan Hukum," Jurnal Analogi Hukum 2, no. 1 (2020): 12-16.
} 
modal. ${ }^{9}$ Dalam artikel ini dikaji mengenai peraturan perundang-undangan terkait program investasi yang dilakukan oleh perusahaan perencana keuangan dan tanggung jawab perusahaan perencana keuangan yang melakukan aktivitas perusahaan di luar anggaran dasar (ultra vires) dan merugikan konsumen.

Berdasarkan latar belakang yang telah diuraikan, maka perumusan permasalahan yang akan diteliti adalah "Bagaimana peraturan perundang-undangan mengatur program investasi oleh perusahaan perencana keuangan yang melakukan kegiatan investasi?" dan "Bagaimana tanggung jawab perusahaan perencana keuangan penyedia program investasi yang merugikan konsumen pengguna jasa investasi dihubungkan dengan kepastian hukum?"

\section{Metode Penelitian}

Penelitian ini merupakan penelitian hukum normatif dengan menggunakan pendekatan konseptual (conceptual approach) dan pendekatan perundang-undangan (statute approach). Penelitian ini menggunakan data sekunder berupa bahan hukum primer (peraturan perundang-undangan) yaitu UU No. 8 Tahun 1995 tentang Pasar Modal, UU No. 8 Tahun 1999 tentang Perlindungan Konsumen, UU No. 40 Tahun 2007 tentang Perseroan Terbatas, UU No. 21 Tahun 2011 tentang Otoritas Jasa Keuangan, PP No. 43 Tahun 2015 tentang Pihak Pelapor dalam Pencegahan dan Pemberantasan Tindak Pidana Pencucian Uang, POJK No. 43/POJK.04/2015 tentang Pedoman Perilaku Manajer Investasi, dan Peraturan PPATK No. 6 Tahun 2017 tentang Penerapan Prinsip Mengenali Pengguna Jasa Bagi Perencana Keuangan, dan Kode Etik Perencana Keuangan. Selain itu, digunakan juga bahan hukum sekunder berupa buku, jurnal, dan internet yang berkaitan dengan permasalahan yang akan dibahas, bahanbahan tersebut akan dijadikan rujukan untuk menyelesaikan permasalahan sebagai bagian dari analisis data. Metode analisis menggunakan konstruksi hukum melalui metode analogi, metode analogi digunakan untuk mencari ketentuan yang khusus menjadi ketentuan umum agar bisa diterapkan terhadap perusahaan perencana keuangan.

\section{Hasil dan Pembahasan}

\subsection{Peraturan Perundang-Undangan yang Mengatur tentang Program Investasi yang Dilakukan oleh Perusahaan Perencana Keuangan}

Suatu perusahaan wajib mentaati dan tidak boleh menyimpang dari peraturan perundang-undangan sebagai wujud dari prinsip responsibility dalam GCG. Penerapan prinsip responsibility dalam GCG dirasakan sebagai suatu tuntutan terhadap peraturan yang ada. ${ }^{10}$ Agar dapat melaksanakan tugas dengan baik, maka UUPT sebagai hukum bagi perusahaan memberikan otoritas yang tidak terbagikan kepada direksi untuk

\footnotetext{
${ }_{9}^{9}$ Lubis and Susanto, "Penerapan Good Corporate Governance Di Pasar Modal Sebagai Upaya Melindungi Investor."

${ }^{10}$ Meythi and Devita L, "Pengaruh Penerapan Good Corporate Governance (GCG) Terhadap Kinerja Keuangan Perusahaan: Studi Empirik Pada Perusahaan Go Public Yang Termasuk Kelompok Sepuluh Besar Menurut Corporate Governance Perception Index (CGPI) Di Bursa Efek Indonesia - MCUreposit," Jurnal Hukum Bisnis Dan Investasi 3, no. 1 (2011), http:// repository.maranatha.edu/2356/.
} 
bertindak mewakili dan mengurus perseroan. ${ }^{11}$ Dalam Pasal 92 ayat (1), Pasal 97 ayat (1) dan (2) UUPT menerangkan bahwa direksi sebagai organ perusahaan yang mengelola dan mengurus perusahaan harus selaras dengan maksud dan tujuan perusahaan yang harus diimplementasikan dengan itikad baik dan penuh tanggung jawab. Jika suatu perusahaan menerapkan konsep GCG, maka pembagian tugas, tanggung jawab, kewenangan, hubungan dan mekanisme kerja dapat berjalan secara harmonis baik secara internal maupun eksternal.12

Perusahaan yang bergerak dalam bidang pasar modal secara khusus merujuk pada UUPM, UU OJK, serta POJK. Perusahaan perencana keuangan adalah perusahaan yang bergerak pada sektor jasa keuangan dan beririsan dengan produk pasar modal serta merupakan penunjang pasar modal, aktivitas yang dilakukan oleh perencana keuangan adalah aktivitas memberikan edukasi mengenai keuangan/investasi, merencanakan suatu strategi dan tujuan keuangan/investasi, membantu mencapai tujuan keuangan/investasi yang sedang dibutuhkan oleh konsumen, konsultasi investasi, dan memberikan solusi atas permasalahan keuangan konsumen maka seharusnya perusahaan perencana keuangan merujuk dan tunduk pada peraturan UUPM, UU OJK serta POJK.

Suatu perusahaan ketika akan menjalankan kegiatan di pasar modal, menyediakan serta menawarkan jasa investasi harus mendapatkan izin dan terdaftar di OJK yang merupakan pengawas dalam kegiatan sektor keuangan. Pembentukan OJK bertujuan agar seluruh sektor yang diawasi oleh OJK dapat terlaksana dengan teratur, transparan, dapat menciptakan sistem keuangan yang stabil dan berkelanjutan dan dapat memberikan perlindungan bagi masyarakat. ${ }^{13}$ Ketentuan Pasal 5 UU OJK menyebutkan bahwa OJK memiliki fungsi agar terselenggaranya sistem pengawasan serta pengaturan terhadap seluruh aktivitas di sektor jasa keuangan. Artinya, suatu perusahaan harus terdaftar di OJK jika akan menyediakan jasa layanan investasi supaya perusahaan tersebut bisa beroperasi secara legal. Peraturan lebih lanjut mengenai kegiatan sektor jasa keuangan di pasar modal diatur dalam POJK, akan tetapi peraturan-peraturan tersebut belum ada yang mengatur mengenai perencana keuangan secara spesifik dan khusus.

Pasal 3 PP No. 43/2015 menyebutkan bahwa perencana keuangan adalah sebagai pihak pelapor, yaitu setiap orang yang wajib menyampaikan laporan kepada PPATK14 dalam rangka pencegahan dan pemberantasan tindak pidana pencucian uang. Perencana keuangan rentan dimanfaatkan oleh konsumennya untuk menyembunyikan asal usul harta kekayaan hasil dari tindak pidana dengan cara bersembunyi dibalik ketentuan kerahasiaan hubungan profesi sesuai dengan ketentuan peraturan perundang-undangan. Peraturan ini bertujuan untuk melindungi setiap orang yang bergerak dalam bidang perencana keuangan dari tuntutan hukum baik secara pidana ataupun perdata akibat adanya pihak yang melakukan tindak pidana pencucian uang. Maka dari itu, dikeluarkanlah Peraturan Pusat Pelaporan dan Analisis Transaksi

\footnotetext{
${ }^{11}$ Hasbullah F Sjawie, “Tanggung Jawab Direksi Perseroan Terbatas Atas Tindakan Ultra Vires," Jurnal Hukum Prioris 6, no. 1 (2017).

12 Yeti Sumiyati, "Peranan BUMN Dalam Pelaksanaan Tanggung Jawab Sosial Perusahaan Untuk Meningkatkan Kesejahteraan Rakyat," Jurnal Hukum Ius Quia Iustum 20, no. 3 (2013): 460-81.

${ }^{13}$ Pasal 4, UU OJK.

${ }_{14}$ Pasal 1 angka 3,PP No. 43/2015.
} 
Keuangan Nomor 6 Tahun 2017 tentang Penerapan Prinsip Mengenali Pengguna Jasa Bagi Perencana Keuangan untuk melaksanakan ketentuan dalam PP No. 43 Tahun 2015 agar perencana keuangan mengenal konsumennya dengan tujuan untuk melindungi perencana keuangan dari tindakan penyelewengan konsumennya.

Kode etik perencana keuangan diterbitkan oleh asosiasi perencana keuangan yaitu Financial Planing Standards Board (FPSB) sebagai lembaga sertifikasi perencana keuangan. Dalam kode etik tersebut hanya disebutkan tanggung jawab profesional dan kode etik perencana keuangan; aturan perilaku bagi profesional RFP (Registered Financial Planner) dan CFP (Certified Financial Planner); standar praktik perencana keuangan; serta pedoman penggunnaan tanda RFP dan CFP. Di dalam kode etik tersebut tidak terdapat sanksi apabila perencana keuangan tidak bertindak sebagaimana seharusnya.

Merujuk pada ketentuan-ketentuan dalam UUPM, UU OJK, POJK, PP No. 43/2015, Peraturan PPATK No. 6/2017, dan Kode Etik Perencana Keuangan maka aktivitas bisnis perusahaan perencana keuangan belum ada pengaturannya secara memadai, terlebih apabila perusahaan perencana keuangan melakukan kegiatan investasi karena sudah jelas apabila ada perusahaan yang bergerak dalam bidang investasi maka harus mendapatkan perizinan dari OJK. Sejauh ini, merujuk pada PP No. 43/2015 dan Peraturan PPATK No. 6/2017 pengaturan mengenai perencana keuangan diterbitkan dalam rangka untuk melaksanakan Undang-Undang Nomor 8 Tahun 2010 tentang Pencegahan dan Pemberantasan Tindak Pidana Pencucian Uang dan tidak secara khusus mengatur tentang eksistensi dan lingkup usaha perusahaan perencana keuangan. Oleh karena itu, perencana keuangan harus dijamin keberadaannya agar mendapatkan kepastian hukum.

Kepastian hukum dan perlindungan hukum sudah seharusnya diberikan karena perencana keuangan merupakan profesi yang memiliki keahlian khusus dan diperlukan untuk kepentingan orang lain. Kepastian hukum diperlukan untuk mewujudkan tujuan tujuan hukum itu sendiri. Kepastian hukum bertujuan untuk memberikan perlindungan terhadap tindakan yang sewenang-wenang. ${ }^{15}$ Kepastian hukum dapat menciptakan standar hukum yang sama bagi masyarakat. ${ }^{16}$ Untuk dapat mewujudkan kepastian hukum maka hukum yang mengikat dan memiliki sanksi yang tegas harus hadir di tengah masyarakat agar memberikan efek didalam penerapan hukum itu sendiri. ${ }^{17}$

Perencana keuangan merupakan profesi yang beririsan dengan produk pasar modal, perencana keuangan adalah salah satu pendukung dan yang menjadi penunjang dalam peningkatan kinerja di sektor pasar modal, perencana keuangan juga memegang peran penting dalam meningkatkan kesadaran masyarakat untuk berinvestasi di pasar modal. Maka dari itu, diperlukan penambahan peraturan mengenai perencana keuangan yang seharusnya dikeluarkan oleh OJK karena lingkup dari perencana keuangan meliputi ruang lingkup dari OJK. Tidak adanya peraturan mengenai perencana keuangan dapat dijadikan celah untuk melakukan kejahatan, dan

${ }^{15}$ Hasaziduhu Moho, "Penegakan Hukum Di Indonesia Menurut Aspek Kepastian Hukum, Keadilan Dan Kemanfaatan," Warta Dharmawangsa 13, no. 1 (2019).

${ }_{16}$ Enrico Simanjuntak, "Peran Yurisprudensi Dalam Sistem Hukum Di Indonesia," Jurnal Konstitusi 16, no. 1 (2019): 83-104.

${ }^{17}$ Maskun, Kejahatan Siber (Cyber Crime) Suatu Pengantar (Jakarta: Kencana, 2013). 
yang melakukan kejahatan itu dapat berhasil lolos dari pengawasan OJK.18 OJK harus segera mengeluarkan peraturan mengenai perencana keuangan agar ruang lingkup batasan kewenangan perencana keuangan jelas dan tidak menyimpang. Dengan adanya peraturan tentang perencana keuangan, perlu diatur tanggung jawab perusahaan tersebut sehingga dapat melindungi konsumen pengguna jasa perencana keuangan. Adanya pengaturan tentang perencana keuangan, tidak hanya bertujuan untuk melindungi perencana keuangan, namun juga harus dapat memberikan kepastian hukum bagi perencana keuangan. Dengan adanya ketentuan yang detail maka pelaksanaan profesi perencana keuangan dapat berjalan dengan jelas dan pasti. Dalam rangka mendukung penguatan kerangka hukum mengenai perencana keuangan perlu dibentuk suatu regulasi khusus berupa peraturan mengenai perencana keuangan yang didalamnya mengatur mengenai kewenangan, sanksi, perlindungan hukum. Dengan demikian, kekosongan undang-undang mengenai perencana keuangan akan menjadi kepastian hukum.

\subsection{Tanggung Jawab Perusahaan Perencana Keuangan Penyedia Program Investasi yang Merugikan Konsumen Pengguna Jasa Investasi Dihubungkan dengan Kepastian Hukum}

Pada pembahasan pertama, telah diungkapkan bahwa peraturan perundangundangan belum secara khusus dan spesifik yang mengatur mengenai aktivitas bisnis perusahaan perencana keuangan terlebih apabila perencana keuangan tersebut melakukan kegiatan investasi. Faktanya telah muncul kerugian dari konsumen yang menginvestasikan dananya pada Jouska yang secara ilegal menjalankan kegiatan investasi. Terdapat kekosongan undang-undang tentang pertanggungjawaban perusahaan perencana keuangan khususnya yang menarik dana investasi yang menimbulkan tidak adanya kepastian hukum untuk mencapai tujuan hukum itu sendiri. Keberadaan kepastian hukum ini sangat penting karena dengan adanya kepastian hukum tidak akan menimbulkan interpretasi yang berbeda-beda sehingga tidak akan berbenturan dan menimbulkan konflik dari ketidakpastian. ${ }^{19}$

Peraturan perundang-undangan tidak jelas bahkan sama sekali tidak mengatur mengenai aktivitas bisnis perusahaan perencana keuangan yang melakukan kegiatan investasi maka dalam pembahasan ini yang akan dilakukan analisis konstruksi hukum melalui metode analogi. Melalui analogi ketentuan yang secara khusus mengatur tentang pelaku usaha yang secara legal menyelenggarakan program investasi, akan diadopsi dan ditarik kedalam ketentuan umum sehingga dapat diterapkan dalam kasus perusahaan perencanaan keuangan yang melakukan kegiatan investasi dalam hal ini adalah Jouska. Analogi yang digunakan merujuk pada ketentuan di dalam UUPM, Undang-Undang Nomor 8 Tahun 1999 tentang Perlindungan Konsumen, dan UUPT, POJK Nomor 43/POJK.04/2015 tentang Pedoman Perilaku Manajer Investasi, serta Kode Etik Perencana Keuangan. Jouska sebagai perusahaan perencana keuangan yang melaksanakan kegiatan usaha diluar tujuan dan maksud perusahaan yang

18 Fallahudin Tsauki Takalamingan, "Peran Otoritas Jasa Keuangan Dalam Melakukan Pengawasan Dan Pencegahan Terhadap Pendirian Perusahaan Investasi Ilegal Di Tinjau Dari Undang-Undang Nomor 21 Tahun 2011," LEX ET SOCIETATIS 9, no. 1 (2021).

${ }^{19}$ Edi Hudiata, "Rekonstruksi Hukum Penyelesaian Sengketa Pasar Modal Syariah: Penguatan Aspek Regulasi Untuk Memberikan Kepastian Hukum," Jurnal Hukum Dan Peradilan 6, no. 2 (2017): 297-316. 
tercantum dalam anggaran dasar, berupa melakukan kegiatan penawaran investasi dan bertindak seolah-olah sebagai manajer investasi, maka pertanggungjawaban Jouska dapat dikenakan secara administratif, perdata, dan pidana. Dasar pertimbangannya adalah dalam POJK No. 43/2015 tentang Pedoman Perilaku Manajer Investasi yang pada intinya mengatur aktivitas perilaku manajer investasi apabila melakukan yang menyimpang dari yang telah ditetapkan dalam peraturan.

Untuk mendapatkan kepastian hukum maka Jouska dapat dikenakan tanggung jawab secara administratif dengan menggunakan analogi melalui Kode Etik Perencana Keuangan dengan POJK 43/2015. Ketentuan dalam Kode Etik Perencana Keuangan menyebutkan bahwa perencana keuangan tidak akan mengkomunikasikan kepada nasabah setiap informasi yang menyesatkan. Selain itu, perencana keuangan tidak boleh melibatkan diri dalam tindakan yang meliputi kebohongan, penipuan, atau secara sadar membuat pernyataan yang menyesatkan nasabah atau pihak lain. Hal ini berbanding terbalik dengan kenyataannya, Jouska sebagai perusahaan perencana keuangan telah beritikad buruk kepada para nasabahnya sebagai konsumen pengguna jasa perencana keuangan untuk membeli investasi yang ditawarkan oleh Jouska. Padahal, Jouska sebagai perusahaan perencana keuangan tidak berwenang untuk melakukan penawaran investasi. Bahkan lebih jauh lagi Jouska turut mengelola dana nasabahnya, seharusnya yang berwenang melakukan itu adalah manajer investasi. Dalam Kode Etik Perencana Keuangan tidak menyebutkan sanksi atau tanggung jawab apabila ada perencana keuangan yang menyimpang dari kode etik, maka untuk mengetahui tanggung jawab dan sanksi perencana keuangan harus digunakan metode analogi melalui POJK 43/2015.

Ketentuan Pasal 37 ayat (2) dan Pasal 44 ayat (1) POJK 43/2015 dapat disimpulkan bahwa manajer investasi dilarang memberikan gambaran yang salah mengenai jasa dan/atau produk yang ditawarkan, dalam hal ini manajer investasi harus menjelaskan semua informasi dengan benar, tidak menyesatkan, dan tidak menyimpang dari peraturan perundang-undangan kepada nasabahnya. Apabila seorang manajer investasi mengingkari ketentuan dalam Pasal 37 ayat (2) dan Pasal 44 ayat (1) POJK 43/2015, manajer investasi memperoleh sanksi administratif sebagaimana tercantum dalam Pasal 49 ayat (1) POJK 43/2015 yaitu dapat berupa peringatan tertulis, denda, pembatasan kegiatan usaha, pembekuan kegiatan usaha, pencabutan izin usaha, pembatalan persetujuan, dan pembatalan pendaftaran. Dengan menggunakan metode analogi melalui POJK 43/2015, pelanggaran oleh perencana keuangan bisa juga dikenakan sanksi administratif seperti yang disebutkan dalam Pasal 49 ayat (1) POJK $43 / 2015$.

Dalam rangka tanggung jawab perusahaan perencana keuangan terhadap konsumen yang dirugikan dikaitkan dengan kepastian hukum, untuk menciptakan kepastian hukum sendiri maka terhadap Jouska dapat dikenakan pertanggungjawaban secara perdata dengan merujuk pada ketentuan dalam UUPT dan UUPK. Pertanggungjawaban perusahaan berarti bahwa setiap konsekuensi yang baik maupun buruk atas perbuatan hukum perusahaan akan ditanggung sendiri oleh perusahaan. UUPT mengatur dan menentukan luasnya kewenangan dan kekuasaan seorang direksi. 20 Direksi dalam menyelenggarakan kewajibannya untuk mengurus dan mewakili perusahaan harus bertanggung jawab serta menjalankannya dengan itikad

${ }^{20}$ Setyarini, Mahendrawati, and Arini, "Pertanggungjawaban Direksi Perseroan Terbatas Yang Melakukan Perbuatan Melawan Hukum." 
baik.21 Tugas, wewenang, dan tanggung jawab direksi dalam mengurus perusahaan semata-mata terbatas bagi kepentingan perusahaan sesuai dengan maksud dan tujuan perusahaan. 22 Apabila direksi melakukan tindakan yang melewati batas kewenangannya ataupun bertentangan dengan anggaran dasar, maka tindakan tersebut dipandang sebagai perilaku pribadi pada direksi dan bukan merupakan tindakan dari perusahaan. ${ }^{23}$ Tindakan direksi yang melewati batas kewenangannya (ultra vires) mempunyai akibat hukum yang hanya mengikat dan menjadi tanggung jawab direksi secara pribadi dengan pihak ketiga, tidak mengikat perusahaan yang diwakili oleh direksi tersebut. ${ }^{24} \mathrm{Hal}$ tersebut sejalan dengan apa yang tercantum dalam Pasal 97 ayat (3) UUPT, apabila terjadi permasalahan pada perusahaan yang disebabkan oleh kesalahan atau kelalaian direksi dalam pengelolaan perusahaan yang menimbulkan kerugian bagi pihak ketiga, maka direksi selaku pemegang tanggung jawab tertinggi dalam sebuah perusahaan harus bertanggung jawab secara pribadi. Artinya, dalam permasalahan ini direksi Jouska harus bertanggung jawab kepada konsumen pengguna jasa dari perusahaan perencana keuangan Jouska yang mengakibatkan kerugian yang tidak sedikit.

Kewajiban direksi Jouska untuk bertanggung jawab secara pribadi kepada nasabah yang dirugikan diperkuat dengan melihat pada peraturan dalam UUPK. Apabila dikaitkan dengan UUPK, dalam Pasal 4 disebutkan bahwa hak konsumen yang dirugikan oleh pelaku usaha adalah berhak untuk mendapatkan ganti kerugian apabila barang dan/atau jasa yang diterima oleh konsumen tidak sesuai dengan perjanjian atau tidak sebagaimana mestinya. Maka, tanggung jawab direksi Jouska secara pribadi bertujuan untuk mengganti kerugian nasabah yang ditimbulkan akibat adanya perbuatan direksi yang melampaui batas kewenangannya (ultra vires).

Selain dapat dikenakan pertanggungjawaban secara administratif dan perdata, Jouska juga dapat dikenakan pertanggungjawaban secara pidana sebagai upaya hukum terakhir. Terhadap pelaku usaha yang secara ilegal melakukan kegiatan diluar anggaran dasar maka dapat dibebankan pertanggungjawaban pidana korporasi dengan merujuk pada peraturan perundang-undangan dan doktrin. ${ }^{25}$ Jouska sebagai perusahaan perencana keuangan tidak berwenang dalam melakukan penawaran investasi dan melakukan kegiatan sebagaimana manajer investasi yang melakukan penawaran investasi serta mengelola dana investasi dan tidak memiliki izin dari OJK, maka jasa investasi yang disediakan oleh Jouska dikatakan ilegal karena tidak mempunyai izin dari OJK. Dalam hal ini merujuk pada Pasal 103 (1) UUPM Jouska dapat dikenakan sanksi pidana penjara paling lama 5 (lima) tahun dan denda paling banyak sebesar Rp. 5.000.000.000,00 (lima miliar rupiah).

${ }^{21}$ Shinta Ikayani Kusumawardani, "Pengaturan Kewenangan, Dan Tanggung Jawab Direksi Dalam Perseroan Terbatas (Studi Perbandingan Indonesia Dan Australia)," Jurnal Magister Hukum Udayana 2, no. 1 (2013): 44100.

${ }^{22}$ Raffles Raffles, “Tanggung Jawab Dan Perlindungan Hukum Direksi Dalam Pengurusan Perseroan Terbatas," Undang: Jurnal Hukum 3, no. 1 (2020): 107-37.

${ }^{23}$ Setyarini, Mahendrawati, and Arini, "Pertanggungjawaban Direksi Perseroan Terbatas Yang Melakukan Perbuatan Melawan Hukum."

${ }^{24}$ Rokhim, “Tindakan 'ULTRA VIRES' Direksi Dan Akibat Hukumnya Bagi Perseroan Terbatas.”

${ }^{25}$ Wibowo and Sumiyati, "Tanggung Jawab Korporasi Fintech Lending Ilegal Dalam Perspektif

Perlindungan Konsumen [Corporate Liability of Illegal Fintech Lending in the Perspective of Consumer Protection Law]." 


\section{Kesimpulan}

Belum ada pengaturan yang secara khusus dan spesifik yang mengatur tentang perencana keuangan berkaitan dengan tugas dan kewenangannya. Kalaupun ada peraturan tersebut ada dalam PP Nomor 43 Tahun 2015 tentang Pihak Pelapor dalam Pencegahan dan Pemberantasan Tindak Pidana Pencucian Uang dan Peraturan PPATK Nomor 6 Tahun 2017 tentang Penerapan Prinsip Mengenali Pengguna Jasa Bagi Perencana Keuangan sebagai pelaksana dari Undang-Undang Nomor 8 Tahun 2010 tentang Pencegahan dan Pemberantasan Tindak Pidana Pencucian Uang. Padahal, eksistensi perusahaan perencana keuangan sedemikian besar dalam mendukung keterarahan perusahaan-perusahaan yang bergerak di bidang pasar modal. Kondisi ini menimbulkan ketidakpastian hukum aktivitas perencana keuangan dan dalam perkembangannya terdapat kegiatan menyimpang yang dilakukan perusahaan perencana keuangan dengan melakukan aktivitas yang tidak sesuai dengan tugas dan maksud perusahaan tersebut dalam anggaran dasar yaitu menyelenggarakan program investasi.

Terhadap Jouska sebagai perusahaan perencana keuangan yang menarik dana investasi dan merugikan banyak konsumen maka dapat dikenai pertanggungjawaban sebagaimana manajer investasi dimintai pertanggungjawaban ketika melakukan pelanggaran terhadap POJK Nomor 43/2015. Dasar pertimbangan analisis ini dilakukan melalui konstruksi hukum analogi karena ketiadaan peraturan yang secara khusus mengatur tentang perencana keuangan. Selain merujuk pada POJK tersebut, analogi juga dilakukan terhadap perusahaan yang bergerak di bidang pasar modal yang tunduk pada UUPM, UUPK, UUPT, dan Kode Etik Perencana Keuangan, sehingga terhadap Jouska seharusnya diberikan sanksi administratif, perdata, dan pidana.

\section{Ucapan terima Kasih (Acknowledgments)}

Penulis mengucapkan terima kasih kepada seluruh pihak yang terlibat dan telah berkontribusi terhadap penulisan artikel ini, khususnya kepada Program Magister Ilmu Hukum Universitas Islam Bandung karena telah mendukung penulis sampai terbitnya artikel ini di jurnal nasional terakreditasi.

\section{Daftar Pustaka}

$\underline{\text { Buku }}$

Maskun. Kejahatan Siber (Cyber Crime) Suatu Pengantar. Jakarta: Kencana, 2013.

\section{Jurnal}

Fauzi, Mohamad Iqbal, and Yeti Sumiyati. "Pertanggungjawaban Developer Perumahan Terhadap Pembangunan Di Kawasan Resapan Air Prespektif Hukum Nasional Dan Hukum Islam." Asy-Syari'ah 23, no. 1 (2021): 103-24.

Hudiata, Edi. "Rekonstruksi Hukum Penyelesaian Sengketa Pasar Modal Syariah: Penguatan Aspek Regulasi Untuk Memberikan Kepastian Hukum." Jurnal Hukum Dan Peradilan 6, no. 2 (2017): 297-316.

Kusumawardani, Shinta Ikayani. "Pengaturan Kewenangan, Dan Tanggung Jawab Direksi Dalam Perseroan Terbatas (Studi Perbandingan Indonesia Dan Australia)." Jurnal Magister Hukum Udayana 2, no. 1 (2013): 44100. 
Lubis, Efridani, and Haryogis Susanto. "Penerapan Good Corporate Governance Di Pasar Modal Sebagai Upaya Melindungi Investor." Jurnal Hukum Dan Bisnis (Selisik) 5, no. 1 (2019): 48-76.

Meythi, and Devita L. "Pengaruh Penerapan Good Corporate Governance (GCG) Terhadap Kinerja Keuangan Perusahaan: Studi Empirik Pada Perusahaan Go Public Yang Termasuk Kelompok Sepuluh Besar Menurut Corporate Governance Perception Index (CGPI) Di Bursa Efek Indonesia - MCUreposit." Jurnal Hukum Bisnis Dan Investasi 3, no. 1 (2011). http://repository.maranatha.edu/2356/.

Moho, Hasaziduhu. "Penegakan Hukum Di Indonesia Menurut Aspek Kepastian Hukum, Keadilan Dan Kemanfaatan." Warta Dharmawangsa 13, no. 1 (2019).

Raffles, Raffles. "Tanggung Jawab Dan Perlindungan Hukum Direksi Dalam Pengurusan Perseroan Terbatas." Undang: Jurnal Hukum 3, no. 1 (2020): 107-37.

Rokhim, Abdul. "Tindakan 'ULTRA VIRES' Direksi Dan Akibat Hukumnya Bagi Perseroan Terbatas." Negara Dan Keadilan 9, no. 2 (2020): 205-17.

Setyarini, Desak Made, Ni Luh Mahendrawati, and Desak Gde Dwi Arini. "Pertanggungjawaban Direksi Perseroan Terbatas Yang Melakukan Perbuatan Melawan Hukum." Jurnal Analogi Hukum 2, no. 1 (2020): 12-16.

Simanjuntak, Enrico. "Peran Yurisprudensi Dalam Sistem Hukum Di Indonesia." Jurnal Konstitusi 16, no. 1 (2019): 83-104.

Sjawie, Hasbullah F. “Tanggung Jawab Direksi Perseroan Terbatas Atas Tindakan Ultra Vires." Jurnal Hukum Prioris 6, no. 1 (2017).

Sumiyati, Yeti. "Peranan BUMN Dalam Pelaksanaan Tanggung Jawab Sosial Perusahaan Untuk Meningkatkan Kesejahteraan Rakyat." Jurnal Hukum Ius Quia Iustum 20, no. 3 (2013): 460-81.

Takalamingan, Fallahudin Tsauki. "Peran Otoritas Jasa Keuangan Dalam Melakukan Pengawasan Dan Pencegahan Terhadap Pendirian Perusahaan Investasi Ilegal Di Tinjau Dari Undang-Undang Nomor 21 Tahun 2011." LEX ET SOCIETATIS 9, no. 1 (2021).

Wibowo, Suseno Adi, and Yeti Sumiyati. “Tanggung Jawab Korporasi Fintech Lending Ilegal Dalam Perspektif Perlindungan Konsumen [Corporate Liability of Illegal Fintech Lending in the Perspective of Consumer Protection Law]." Law Review, 2021, 117-44.

\section{Peraturan Perundang-Undangan}

Undang-Undang Nomor 8Tahun 1995 tentang Pasar Modal.

Undang-Undang Nomor 8 Tahun 1999 tentang Perlindungan Konsumen.

Undang-Undang Nomor 40 Tahun 2007 tentang Perseroan Terbatas.

Undang-Undang Nomor 21 Tahun 2011 tentang Otoritas Jasa Keuangan.

Peraturan Pemerintah Nomor 43 Tahun 2015 tentang Pihak Pelapor dalam Pencegahan dan Pemberantasan Tindak Pidana Pencucian Uang.

Peraturan Menteri BUMN Nomor PER-09/MBU/2012 tentang Perubahan Atas Peraturaan Menteri BUMN Nomor PER-01/MBU/2011 tentang Penerapan Tata Kelola Perusahaan yang Baik (Good Corporate Governance) Pada Badan Usaha Milik Negara.

POJK Nomor 43/POJK.04/2015 tentang Pedoman Perilaku Manajer Investasi.

Peraturan Pusat Pelaporan dan Analisis Transaksi Keuangan Nomor 6 Tahun 2017 tentang Penerapan Prinsip Mengenali Pengguna Jasa Bagi Perencana Keuangan. 


\section{Website}

Indonesia, Allianz. "Yuk, Mengenal Profesi Perencana Keuangan Yang Tengah Hits!" Accessed April 9, 2021. https://www.allianz.co.id/explore/yuk-mengenalprofesi-perencana-keuangan-yang-tengah-hits.html.

Setiawan, Sakina Rakhma Diah. "OJK Rumuskan Aturan Pengawasan Perencana Keuangan." Accessed April 5, 2021. https://money.kompas.com/read/2014/02/28/1521518/OJK.Rumuskan.Atura n.Pengawasan.Perencana.Keuangan. 